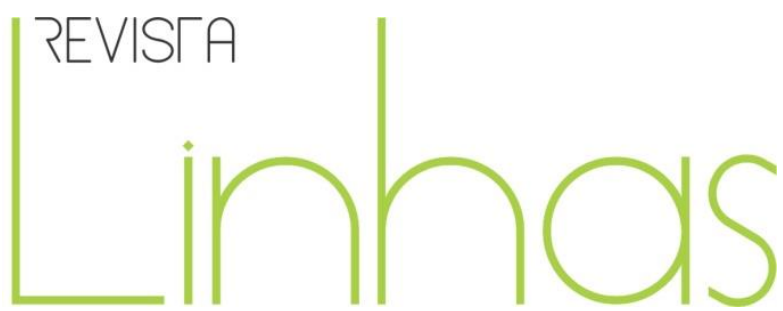

\title{
Resenha do livro "La pantalla global: cultura y cine en la era hipermoderna"
}

LIPOVETSKY, Gilles; SERROY, Jean. La pantalla global: cultura y cine en la era hipermoderna. Traducción Antonio-Prometeo Moya. Barcelona: Editorial Anagrama, 2010.

\section{Fernando Cesar Sossai}

Professor na Universidade da Região de Joinville - Univille. Doutorando em Educação pela Universidade do Estado de Santa Catarina - UDESC - Brasil fernandosossai@gmail.com

\section{Para citar esta resenha:}

SOSSAI, Fernando Cesar. Resenha do livro "La pantalla global: cultura y cine en la era hipermoderna". Revista Linhas. Florianópolis, v. 17, n. 33, p. 333-337, jan./abr. 2016.

\section{DOI: $10.5965 / 1984723817332016333$}

http://dx.doi.org/10.5965/1984723817332016333 
Pantalla en todo lugar y todo momento, en las tiendas y en los aeropuertos, en los restaurantes y los bares, en el metro, los coches y los aviones; pantalla de todos los tamaños; pantallas para cada cual, pantallas completas con cada cual; pantalla para hacerlo y verlo todo. Videopantalla, pantalla miniaturizada, pantalla gráfica, pantalla nómada, pantalla táctil: el nuevo siglo es el siglo de la pantalla omnipresente y multiforme, planetaria y multimediática. (LIPOVETSKY; SERROY, 2009, p. 10)

Estamos na era da "pantalla global". Eis o argumento fundamental que dá impulso às reflexões de Gilles Lipovetsky e Jean Serroy no livro La pantalla global: cultura y cine en la era hipermoderna.

Mais do que um debate sobre o lugar tecnológico ocupado pelo cinema nas globalizadas sociedades que em vivemos, os autores promovem um refinado debate ao redor das seguintes indagações: “¿Qué es el cine en la época de la pantalla global?” e “QQué efectos tiene esta proliferación de pantallas en nuestra relación con el mundo y con los demás, con nuestro cuerpo y nuestras sensaciones?" (LIPOVETSKY; SERROY, 2009, p. 10 e 27).

Num total de 352 páginas, tais questões são enfrentadas ao longo de três Partes. Na primeira, intitulada Lógicas del Hipercine, os autores nos oferecem um debate sobre os principais conceitos que estruturam a sua obra, destacadamente uma análise sobre o que chamam de Hipercine, sua constituição histórica, sua articulação e seus impactos sobre o consumo social do cinema, as transformações que exigiu do suporte pelo qual historicamente se expressou, isto é, as maneiras pelas quais produziu e difundiu suas próprias imagens em movimento.

\footnotetext{
${ }^{1}$ De maneira geral, tal conceito remete "[...] al nuevo dominio planetario de la pantallasfera, al estadopantalla generalizado que se ha vuelto posible gracias a las nuevas tecnologías de la información y la comunicación. Son los tiempos del mundo pantalla, de la todopantalla, contemporánea de la red de redes, pero también de las pantallas de vigilancia, de las pantallas informativas, de las pantallas lúdicas, de las pantallas de ambientación". (LIPOVETSKY; SERROY, 2009, p. 22)
} 
Em continuidade, em Neomitologías, Lipovetsky e Serroy (2009) retomam alguns dos elementos analíticos apresentados nos capítulos anteriores com o intuito de promover uma discussão pontual em relação às "cuatro edades del cine" ${ }^{2}$, desta forma, evidenciar como foram se forjando tipologias/mitologias cinematográficas, tais como a ideia de classificar os filmes fazendo uso de critérios/atribuições que lhes são externos, a partir do seu suposto gênero, do sobrenome de seu diretor, de sua presumível rotulação étnica/cultural, de suas possibilidades de inserção comercial, entre outros.

Já na terceira parte, Todas las Pantallas del Mundo, os autores dedicam especial atenção à análise sobre como o cinema foi se tornando uma espécie de moldura para se olhar o mundo em que vivemos. Para eles, o século XX foi o século “de la gran pantalla” e não há como negar que o cinema nos penetrou de tal forma que passamos a distendê-lo em práticas sociais que não imaginávamos atinentes aos seus domínios. Nas palavras de Lipovetsky e Serroy (2009, p. 25):

Mucho más allá de los programas audiovisuales, el espíritu del cine se ha apoderado de los gustos y comportamientos cotidianos [...]. Filmar, enfocar, visionar, registrar los movimientos de la vida y de mi vida: todos estamos a un paso de ser directores y actores de cine, casi a un nivel profesional. Lo banal, lo anecdótico, las grandes catástrofes, los conciertos, los actos de violencia son hoy filmados por los actores de su propia vida.

De um ponto de vista metodológico, os autores propõem um "enfoque global” do cinema, negando-se a estudá-lo “como un puro sistema autónomo de signos". Para eles, trata-se de lutar contra a "reducción semiológica o estética" dos filmes, avançando para além do "circuito cerrado de la gramática del cine, volviendo a vincularlo con lo que lo

\footnotetext{
${ }^{2}$ Segundo os autores, o cinema ocidental possuiria quatro idades. A primeira (começo do século XX até os anos 1930), corresponderia a "época del cine mudo" e refletiria a "modernidad primitiva" do cinema. Já a segunda (início dos 1930 até os 1950), "pone en escena una modernidad clásica" que, por sua vez, "es la edad de oro de los estudios, la época en que el cine es el principal entretenimiento de los estadounidenses, la época en que se convierte en todo el mundo en el ocio popular por excelencia" (LIPOVETSKY; SERROY, 2009, p. 17). A terceira (dos 1950 até os 1970) seria representada pela "modernidad vanguardista y emancipadora" no cinema (LIPOVETSKY; SERROY, 2009, p. 19). E, finalmente, depois dos anos 1980, a "cuarta época del cine" chamada de "hipermoderna, por referencia a la nueva modernidad que se construye" (LIPOVETSKY; SERROY, 2009, p. 21).
} 
engloba". Dito de outra maneira, uma análise em cinema não necessariamente precisa criar um arranjo metodológico que dê conta de averiguar/sistematizar as "estructuras universales del lenguaje cinematográfico ni hacer una clasificación de las imágenes”. O fundamental é:

[... ] poner de relieve lo que dice el cine sobre el mundo social humano, cómo lo reorganiza, pero también cómo influye en la percepción de las personas y reconfigura sus expectativas. Ni sistema cerrado ni puro espejo social, el cine debe interpretarse de forma global, por dentro y por fuera, como efecto y como modelo imaginario. (LIPOVETSKY; SERROY, 2009, p. 27)

Ademais, vale a pena registrar as principais motivações que levaram Gilles Lipovetsky e Jean Serroy à escrita de seu livro. Da perspectiva desses pensadores, La pantalla global foi redigido como uma espécie de manifesto contra a "[...] idea melancólica de la 'poscinematografía' que sigue alimentando ampliamente el discurso crítico". Ou seja, o que buscam enfatizar é que "el 'verdadero' cine no está detrás de nosotros" (LIPOVETSKY; SERROY, 2009, p. 12 e 13). Ao contrário, está conosco como parte de uma "cinevisión" do mundo; como elemento que contribui para a construção de “una percepción del mundo" (LIPOVETSKY; SERROY, 2009, p. 320). Daí que um "estilocine" parece ter "invadido el mundo" e segue hoje dando ininterruptas "muestras de su diversidad, su vitalidad y su inventiva" (LIPOVETSKY; SERROY, 2009, p. 325).

A todos/as que se interessam pelo debate científico, rigoroso e instigante sobre a onipresença de pantallas em nossa vida cotidiana - sejam pantallas cinematográficas ou não -, recomendo fortemente a leitura. 


\section{Referência}

LIPOVETSKY, Gilles; SERROY, Jean. La pantalla global: cultura y cine en la era hipermoderna. Traducción Antonio-Prometeo Moya. Barcelona: Editorial Anagrama, 2010.

Recebido em: 12/12/2015 Aprovado em: 19/02/2016

Universidade do Estado de Santa Catarina - UDESC Programa de Pós-Graduação em Educação - PPGE

Revista Linhas

Volume 17 - Número 33 - Ano 2016 revistalinhas@gmail.com 